\title{
Strategies to Develop Sawahlunto Old City in West Sumatera as Tourism Destination
}

\author{
Febby Salam $^{1}$, Rahmat Ingkadijaya ${ }^{2}$, Hengky Hermantoro ${ }^{3}$ \\ 1,2,3 Sekolab Tinggi Pariwisata Trisakti \\ 1Febbysalam@gmail.com
}

\begin{abstract}
Tourism development in an area is able to give an impact on various dimensions of local people life. One of the impacts of tourism development is on the economic dimension. It happened to Sawahlunto, a city in West Sumatera famous for its coal mines, which slowly developed into a tourist city. The purpose of this study was to find out the Strength \& Weakness, Opportunity \& Threat and to formulate the development strategy of Kota Tua as a tourism destination in Sawahlunto, West Sumatra. The research method is descriptive method using SWOT analysis. The results showed that the development strategy of the Old City area of Sawahlunto used a lot of SWOT analysis, namely by increasing and optimizing natural resources through good processing, improving road access, and improving the tourism sector of Old City Sawahlunto. Another strategy is improving human resources through counseling and training, socialization of science and technology. The tourism potential of Sawahlunto old town on the 4A tourism component (Attraction, Accessibility, Amenities and Ancillary) shows that this area has the potential of historical tourist attraction. The historical heritage of World War II in Sawahlunto is the main tourism potential that is stored. With historical tourism potential, foreign tourists are the target of tourists who are expected to visit Sawahlunto. In order for a historical tourism potential strategy to be implemented, it is necessary to meet the minimum criteria of the tourism component. To meet the service standards of all 4A tourism components, it is necessary to improve the management of 4A tourism components including Attraction, Accessibility, Ancillary, and Amenity.
\end{abstract}

Keywords: Development Strategy, Sawahlunto Old City, Tourism Destinations, SWOT Analysis. 


\section{A. Introduction}

Tourism can be used as a catalyst for development. Tourism development activities, are long links that can mobilize various activities in people's lives. One sector that is driven is the economic sector. A large proportion of the workforce is absorbed into tourism activities as direct and working labor in the supporting sector. All of this will expand employment opportunities while distributing equity (Spillane, 1987:60).

The number of tourist visits in Sawahlunto City During 2017 was increasing compared to the previous year. In 2016 there were 737,012 people visited Sawahlunto City while in 2017 the number reached 114,003 people. Tourist attractions in Sawahlunto which are most visited by tourists are Kandi Animal Park, which is located in Talawi District which is in the post-coal mining area, then Waterboom which is located in Silungkang District. Judging from the visit of tourists, recreational tourism objects are more desirable for tourists in Sawahlunto City when compared to cultural and historical Attractions (http://sawahluntotourism.com/index.php/About-Us-Tentang-Sawahlunto kunjunganwisatawan-Kota-Sawahlunto).

One of the programs and activities that have been carried out by the Sawahlunto City Government is the inventory of historic old buildings carried out in 2002. This activity also re-illustrates the shape of the building, the front, left and right sides as well as the back, floor plan and function of the previous building. Some of the buildings that are now cultural heritage do have different usage histories from the time they were established, up to the time of the inventory.

Preservation of the Old City Area Sawahlunto as one of the tourism development programs of Sawahlunto City is a long-term program and cannot be separated from the preservation of the characteristics of the Old City and Cultural Heritage Buildings and the culture of the local community. The preservation of the Old City Area is expected to be carried out not only by the City Government, but most importantly involving the local community. Thus the tourism development strategy must be oriented to the effort to involve the community both in the process of planning, organizing, implementing and supervising which in the end will be able to realize tourism development that can improve the welfare of the local community.

Seeing the slow efforts made by the West Sumatra government in developing the old city area into a tourist area, encourages researchers to conduct this study, to further identify the constraints faced by the government and other parties involved in the development efforts that have been made so that can be used as input or consideration in the development of the right development strategy in the future, in accordance with the potential, problems, and activities that develop in the region at this time.

Problems related to the tourism area of Sawahlunto City are low tourist attraction, lack of accessibility, human resources, law enforcement, marketing, 
environmental awareness, institutional services, and business climate development. The complexity of the problems faced requires the right solution so that the competitiveness and sustainability of the city environment is maintained. Without development planning to overcome the problems faced by Sawahlunto City as a tourist destination, it is feared that competitiveness will weaken, thereby reducing the sustainability of the environment and the region itself. Therefore, as a step in planning the development of a competitive and sustainable tourism area for the old city of Sawahlunto, it is necessary to develop a competitive and sustainable tourism area strategy model which in the future is expected to become one of the models for developing tourism areas for other cities. in Indonesia. SWOT analysis is one of the ways to establish strategies in developing the area, and previous research showed the examples of SWOT analysis in tourism area in the city, such as Pesindon in Pekalongan (Suprina, R \& Nathania (2018)

The purpose of this study is as follows:

a. To find out the potential of the Old City of Sawahlunto, West Sumatra as a tourism destination.

b. To find out the obstacles in the development of Sawahlunto.

c. To formulate the development strategy of Sawahlunto as a tourism destination using SWOT analysis

\section{B. Literature Review}

\section{Tourism Industry}

Christie Mill and Marrison (Ardhika Sukmasakti Hasworo 2012: 5) said that "Tourism is a phenomenon or phenomenon that is difficult to explain. Can misinterpret tourism as an industry, because the real idea is to provide a unified idea about tourism, so that its impression is seen from a political and economic point of view will be more attractive and get the support of many people". The description of tourism as an industry is given only to describe tourism concretely, thus giving a clearer understanding.

So the tourism industry aims more to convince people that tourism has a positive impact on the economy, especially the impact of the multiplier effect it causes. Tourism as an industry unlike the manufacturing industry is known, but the tourism industry is not independent and is more intangible, the tourism industry is also called an industry without a smokeless industry (Yoeti, 2008: 111).

According to Spillane (1987: 87-88) there are several special characteristics regarding the tourism industry, namely:

a. Tourist products have the characteristic that they cannot be moved. People cannot bring tourism products to customers, but the subscribers themselves must visit, experience and come to enjoy the tourism products. 
b. In tourism production and consumption occur at the same time. Without a subscription that is using these services there will be no production.

c. As a service, tourism has various forms. Therefore, in the field of tourism there is no objective measurement standard, as other real products, for example there is a length, width, content, capacity, etc. like in a car.

d. Subscriptions cannot taste the product before even not knowing or testing the product before. What can only be seen are brochures, pictures.

e. In terms of business, tourism products are businesses that carry a large risk. The tourism industry requires large investments, while demand is very sensitive to changes in the economic, political, public attitudes or pleasure of tourists and so on.

\section{Tourism Development}

According to Law No. 10 of 2009 concerning tourism, article 4, the objectives of tourism development are:

a. Increase economic growth

b. Improve people's welfare

c. Eradicate poverty,

d. Overcoming unemployment

e. Preserve nature, environment and resources,

f. Advancing culture,

g. Lift the image of the nation,

h. Cultivate a sense of love for the country,

i. Strengthen the identity and unity of the nation,

j. Strengthen friendship between nations. In the context of tourism, tourism development is increasing tourism objects, improving the quality of services, expanding and diversifying tourism objects and other accommodation.

According to Pitana and Diarta (in Ashartono, Rahmanita, \& Lemy, 2018), tourism development and development should be based on local wisdom and special local sense that reflects the uniqueness of cultural heritage and the uniqueness of the environment. So tourism development is an effort to exploit natural and cultural potential, by considering aspects of conservation. Tourism development is an effort that is done consciously and planned to explore, improve and advance the potential that exists in a tourist destination both physically and socially to increase people's income and foreign exchange by preserving cultural identity and minimizing its negative impacts. Tourism development aims to improve the welfare of the community by distributing income equally.

\section{Tourism Destination Development}

According to Law number 10 of 2009 concerning tourism, tourist destinations, hereinafter referred to as tourism destinations, is a specific geographical area which is in one or more administrative areas in which there are 
tourism activities and are equipped with the availability of tourist attractions, public facilities, tourism facilities, accessibility. and interrelated communities.

According to Cooper et al in Sunaryo (2013: 159) explains that the development framework of tourism destinations consists of the following main components:

a. The attraction which includes the uniqueness and attractiveness based on nature, culture, or artificial / artificial.

b. Accessibility which includes the ease of transportation facilities and systems.

c. Amenities which include supporting facilities and supporting tourism.

d. Public facilities (Ancillary Service) that support tourism activities.

e. Institutions that have the authority, responsibility and role in supporting the implementation of tourism activities.

\section{Aspect of 4A (Attraction, Accessibility, Amenities, Ancillary Service).}

\section{a. Attraction}

According to Suwena (2010: 88), attractions or objects of tourist attraction (ODTW) are significant components in attracting tourist arrivals. Things that can be developed into tourist attractions are called capital or tourism sources (tourism resources). There are three main attractions for tourists, namely 1) Natural Resources such as mountains, lakes, beaches and hills; 2) Cultural tourism attractions such as traditional house architecture in the village, archaeological sites, arts and crafts, rituals, festivals, daily community life, hospitality, food; and 3) Artificial attractions such as sporting events, shopping, exhibitions, conferences and others. Tourism capital according to Suwena (2010: 89) can be developed into tourist attractions in places of tourist capital found (in situ) and outside its original place (ex situ). Distinguished tourist attractions become attraction attractions and tourist attraction attractions

\section{b. Accessibility}

According to Sunaryo (2013: 173), tourism accessibility is intended as "all means that provide convenience to tourists to reach a destination or related tourist destination". According to French in Sunaryo (2013: 173) mentions factors that are important and related to aspects of tourist accessibility include directions, airports, terminals, time needed, travel costs, frequency of transportation to tourist sites and other devices.

\section{c. Amenities}

Sugiama (2011: 89) explains that amenitas includes "a series of facilities to meet the needs of accommodation (lodging), provision of food and beverages, entertainment venues (entertainment), shopping places (retailing) and other services". French in Sunaryo (2013: 173) gives the limit that amenity is not an attraction for tourists, but with a lack of amenitas will make tourists avoid certain destinations. 


\section{d. Ancillary Service}

Sunaryo (2013:159) describes ancillary service more to the availability of public facilities and used by tourists which also support the implementation of tourism activities such as banks, ATMs, telecommunications, hospitals and so on. While Sugiama (2011) explained that ancillary service includes the existence of various organizations to facilitate and encourage the development and marketing of tourism in the destination concerned.

\section{Research Methodology}

\section{Research Approach and Research Design}

According to Burhan (2011: 27) qualitative research is research that uses an inductive approach, thus the theory is actually a tool that will be tested later with data and research instruments. It is further clarified that qualitative research methods are often called naturalistic research methods because their research is carried out under natural conditions, and also called ethnographic methods because at first this research was widely used for research in the field of social anthropology due to data collected and the analysis was more qualitative (Sugiyono, 2014: 14).

While the type of research carried out is the type of descriptive research where all the data information available in the field will be described in a complex manner and facilitate the researcher in analyzing the data and making it easier for the reader to understand the problems that are the core of this research. So that in the use of the approach and design of this research is as an effort for researchers to describe in writing about the problems of this research and compile research reports that are complex and efficient so that the purpose of this study can be answered. In this study the author describes the history and the Old City as a tourism destination in the city of Sawahlunto, West Sumatra.

\section{Primary data}

Primary data is data that originates from the original or first source. This data is not available in the form of compiled or in the form of files. This data must be sought through the resource person or in technical terms the respondent, that is, the person we make the object of research or the person we make as a means of obtaining information or data. Based on the data source studied, the source of data collection that I use is:

a. Observation

In this study observation techniques are used to strengthen data, especially learning activities and teacher performance. Thus the results of this observation at the same time to confirm the data that has been 
collected through interviews with the actual reality. This observation is used to observe directly and indirectly about history and the Old City as a tourism destination in Sawahlunto City, West Sumatra.

\section{b. Interview}

Interviews conducted in two forms, namely structured interviews (carried out through questions that have been prepared in accordance with the problems to be examined). While unstructured interviews (interviews are conducted if there is an answer develops beyond structured questions but cannot be separated from research problems) (Arikunto, 2006: 72). In this study, interviews were used to conduct communication with related parties or research subjects, including $\mathrm{Mr}$. Asnawi Bahar, (Chairperson of the Asian DPP) and Mr. Doni Askaria (Commissioner of Garuda / West Sumatra Tourism Activist) in order to obtain explanations or information about matters that have not been listed in the observation and documentation.

\section{c. Documentation}

Document analysis is carried out to collect data sourced from archives and documents both at school and outside of school, which are related to the research. According to Arikunto (2012: 132), documentation techniques are "finding data about things or variables in the form of notes, transcripts, books, newspapers, magazines, inscriptions, minutes of meetings, agendas and so on".

\section{Secondary data}

Secondary data sources are data sources that do not directly provide data to data collectors (Sugiono: 2014: 402). This secondary data is data that supports the needs of primary data such as books, literature and related readings.

\section{Data analysis method}

\section{a. Data reduction}

Which begins with the researcher looking for and collecting the results of interviews and documentation related to the company's promotion strategy. The data that researchers have collected from these resource persons will be grouped and carried out the checking process through data triangulation to be chosen again based on needs and suitability with the research, so that data that is not needed will be sorted / discarded. The next step is simplification of data / research results through coding so that data is easy understood and easily presented, which is summarized in the form of data reduction tables so as to facilitate the withdrawal of final conclusions. 
Strategy For Development Of Old City As Tourism Destination In Sawahlunto City,

b. Data Presentation,

Conducted by categorizing and compiling a collection of data / information in order to get a complete and systematic picture to facilitate conclusions and take action. The data presentation used in this qualitative research is narrative text, both in the form of brief descriptions, charts, tables, relationships between categories, and easy-to-understand flowcharts.

c. Withdrawal of Conclusions,

What is done when researchers can design strategies for developing tourism attractions in Sawahlunto Old Town to attract tourists to visit with the support of credible evidence

The diagram of the SWOT analysis proposed by Rangkuti (2008: 19) can be seen in Table 1 below:

Table 1 Matriks SWOT Kearns

\begin{tabular}{|c|c|c|}
\hline EXTERNAL & OPPORTUNITY & THREAT \\
\hline STRENGTH & $\begin{array}{c}\text { Comparative } \\
\text { Advantage }\end{array}$ & Mobilization \\
$(\mathrm{O} / \mathrm{S})$ & $(\mathrm{T} / \mathrm{S})$ \\
\hline WEAKNESS & Divestment/Investment & Damage Control \\
& $(\mathrm{O} / \mathrm{W})$ & $(\mathrm{T} / \mathrm{W})$ \\
\hline
\end{tabular}

Source: Ronchetti, 2011

Because in this study focus on the application of SWOT analysis (Strength, Weakness, Opportunity, Threatens), the data analysis will also be analyzed using the Threats-Opportunities-Weaknesses-Strengths (TOWS) Matrix method which is an important matching tool to help managers develop four types of strategies. The four types of strategies in question are:

SO Strategy (Strength-Opportunity). This strategy uses the company's internal strength to reach opportunities outside the company. In general, companies try to implement WO, ST, or WT strategies to implement SO strategies. Therefore, if the company has a lot of weaknesses, inevitably the company must overcome these weaknesses to become strong. Whereas, if the company faces a lot threat, the company must try to avoid it and try to concentrate on the opportunities that exist. 
WO Strategy (Weakness-Opportunity). This strategy aims to minimize internal weaknesses of the company by utilizing external opportunities. Sometimes companies face difficulties to take advantage of opportunities because of internal weaknesses.

ST (Strength-Threat) Strategy. Through this strategy the company strives to avoid or reduce the impact of external threats. This does not mean that a strong company must always be threatened.

Weakness-Threat (WT) Strategy. Is a defensive tactic that is directed to reduce internal weaknesses and avoid external threats. An organization that faces various external threats and internal weaknesses is really in a dangerous position. In fact, such companies may have to struggle to survive, merge, contract, declare themselves bankrupt, or choose liquidation.

D. Results

Internal Analysis

1. Attraction

\begin{tabular}{|l|l|l|}
\hline $\mathbf{S}$ & 1. Having a variety of attractions and attractions with very interesting
\end{tabular} and diverse historical tourism potential.

2. Famous in foreign countries, especially Europe with the image of a region that has been famous since the VOC era

3. The nature of public openness to foreigners

W 1. Management of the museum (open schedule, exhibition schedule)

2. Management of exhibition objects in the museum

3. Guide with foreign language skills

\section{Amenities}

\begin{tabular}{|c|c|}
\hline $\mathbf{S}$ & $\begin{array}{l}\text { 1. The availability of a place to stay is adequate restaurants or restaurants } \\
\text { that sell food, typical of an area will be of particular interest in the eyes } \\
\text { of tourists. } \\
\text { 2. The travel agency offers a variety of tour packages ranging from } \\
\text { conventional tour packages that only surround the sites or Cultural } \\
\text { Heritage only or education-based tour packages, and others. } \\
\text { 3. Availability of souvenir shops in the Kuta Tua Sawahlunto area the } \\
\text { number of restaurants is relatively small compared to the number of } \\
\text { accommodations } \\
\text { 4. The location is sometimes difficult to reach by tourists. }\end{array}$ \\
\hline $\mathbf{W}$ & $\begin{array}{l}\text { 1. The tourism information center is only in the form of a Promotion } \\
\text { Agency managed by the Department of Tourism and Culture } \\
\text { 2. A tourism information center (TIC / Tourism Information Center) in } \\
\text { the area of the old town of Sawahlunto still does not exist, } \\
\text { 3. The area of Sawahlunto's old city site is also not available for money } \\
\text { changers. }\end{array}$ \\
\hline
\end{tabular}




\section{Aksesbilitas}

\begin{tabular}{|l|l|}
\hline $\mathbf{S}$ & 1. There are transportation, directions, airports, stations or terminals, \\
& $\begin{array}{l}\text { 2. The highway has been cast } \\
\text { 3. There are already many directions at each intersection leading to many } \\
\text { tourist sites }\end{array}$ \\
\hline $\mathbf{W}$ & $\begin{array}{l}\text { 1. There is still no special transportation to the Sawahlunto area so } \\
\text { tourists who do not use travel services will find it difficult to go to } \\
\text { tourist sites. }\end{array}$ \\
& $\begin{array}{l}\text { 2. } \\
\text { tourists who are confused when visiting the old town of Sawahlunto }\end{array}$ \\
\hline
\end{tabular}

\section{Ancillary Service}

\begin{tabular}{|c|c|}
\hline & $\begin{array}{l}\text { 1. General facilities are supportive } \\
\text { 2. The security post already has coordination between the police and the } \\
\text { Koramil to oversee tourism activities in the old town of Sawahlunto, } \\
\text { 3. There is already a hospital or clinic } \\
\text { 4. Availability of public facilities of good standard } \\
\text { 5. Cleanliness of public facilities is of good standard } \\
\text { 6. Availability of facilities for safety, security and health standards in the } \\
\text { Old City of Sawahlunto }\end{array}$ \\
\hline & $\begin{array}{l}\text { 1. There are no special officers such as tourist police, and others. } \\
\text { 2. Bank and ATM facilities are only in certain locations that are } \\
\text { sometimes difficult to reach by tourists }\end{array}$ \\
\hline
\end{tabular}

\section{External Analysis}

\section{Policy}

\begin{tabular}{|l|l|}
\hline $\mathbf{S}$ & $\begin{array}{l}\text { 1. } \\
\text { Preservation of Cultural Heritage Sawahlunto old town which is } \\
\text { under the Directorate of Education and Culture. } \\
\text { 2. There has been cooperation in the development of Sawahlunto Old } \\
\text { Town area as evidenced by the existence of a Memorandum of } \\
\text { Understanding (MoU) between the two parties }\end{array}$ \\
$\mathbf{W}$ & $\begin{array}{l}\text { 1. Lack of funds, lack of promotion and lack of infrastructure and } \\
\text { facilities to support tourism activities }\end{array}$ \\
\hline
\end{tabular}

\section{Economy}

\begin{tabular}{|l|l|}
\hline $\mathbf{S}$ & $\begin{array}{l}\text { 1. The number of tourist visits and support from the government is also } \\
\text { one of the drivers in the development of the old town area of } \\
\text { Sawahlunto. }\end{array}$ \\
\hline $\mathbf{W}$ & 1. The emergence of new entertainment centers such as malls \\
\hline
\end{tabular}




\section{Socio Cultural}

\begin{tabular}{|l|l|}
\hline $\mathbf{S}$ & $\begin{array}{l}\text { 1. The big name of the kingdom will certainly facilitate the promotion of } \\
\text { cultural tourism, so that many tourists are interested in visiting the } \\
\text { Old City area of Sawahlunto }\end{array}$ \\
\hline $\mathbf{W}$ & 1. Low public awareness of historical heritage \\
\hline
\end{tabular}

\section{Technology}

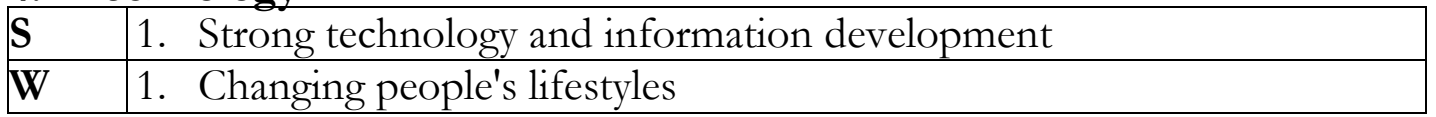

\section{Sawahlunto Old Town Development Strategy}

\begin{tabular}{|c|c|}
\hline Strategy & Explanation \\
\hline $\mathbf{S}-\mathbf{O}$ & $\begin{array}{l}\text { 1. Old Town historical tour packages and other tours around } \\
\text { Sawahlunto } \\
\text { 2. Collaboration to develop scheduled and low-cost transportation } \\
\text { modes for visits to Sawahlunto } \\
\text { 3. The collection of struggles since } 1945 \text { which is a potential to be } \\
\text { further developed } \\
\text { 4. Holding a collaboration event } \\
\text { 5. A more in-depth approach with the community } \\
\text { 6. More use of the land to the fullest }\end{array}$ \\
\hline$S-T$ & $\begin{array}{l}\text { 1. Strategic location that can be developed to compete with similar } \\
\text { tourism objects } \\
\text { 2. Creating an old city with a new, more modern feel } \\
\text { 3. Increasing local cultural celebrations into tourist attractions } \\
\text { 4. Creating a cultural studio for the preservation of local traditions }\end{array}$ \\
\hline $\mathbf{W}-\mathbf{O}$ & $\begin{array}{l}\text { 1. Improving the quality of support services at destinations; } \\
\text { clean toilet, hygienic restaurant, improved hotel standards. } \\
\text { 2. Provision of regulations to protect the environment by } \\
\text { applying the old town of Sawahlunto as a conservation area } \\
\text { so that tourists who come are not mass tourism } \\
\text { 3. Community empowerment to improve regional handicrafts } \\
\text { and souvenirs } \\
\text { 4. Increase promotion by army personnel } \\
\text { 5. Collaborative relationships that can be developed } \\
\text { 6. Submit a proposal for cooperation with several parties }\end{array}$ \\
\hline $\mathbf{W}-\mathbf{T}$ & $\begin{array}{l}\text { 1. Improving infrastructure that is still lacking } \\
\text { 2. Providing maximum service with a guide who is always } \\
\text { available } \\
\text { 3. Need policies and regulations to regulate the preservation of } \\
\text { relics } \\
\text { 4. Improved coordination between relevant institutions to } \\
\text { support tourism }\end{array}$ \\
\hline
\end{tabular}


The Culture and Tourism Office of the Old Town Area of Sawahlunto set strategic goals and objectives based on the vision and mission that will be achieved within the next one to five years. The programs, activities, objectives and strategic targets of Sawahlunto Old Town are as follows:

1. Short Term Strategy

Strategy 1:

- Utilizing old buildings \& buildings that have a high historical value along the Old City area to support tourism activities

Target:

- Maintain the existence and preservation of old buildings and the environment in the Old City Area

- Introducing the public to old buildings and buildings that have a high historical value in the study area

Programs and activities in this strategy are:

a. Old town revitalization program with the following activities:

b. Improve the quality of old buildings in the study area

c. Providing incentives to old building owners to carry out maintenance

d. Activity development program that is relevant to old buildings with the following activities:

e. Hold photography competitions or paint with themes related to old buildings

f. Providing Sawahlunto Old City tour packages such as excursion tour. Excursion tour is a tour using coach-bus or taxi for city sightseeing, local tour, one day tour, for a round trip day trip. Usually, in the implementation of this tour visit local attractions guided by a guide.

Strategy 2:

- Utilizing support from organizations caring for the old city to support tourism activities.

Target:

- Creating an atmosphere of good cooperation and coordination between the parties involved in carrying out the development plan of the old city.

- Programs and activities in this strategy are:

- Program to increase participation and appreciation of organizations / institutions concerned about the old city in the development plan of old city tourism with the following activities:

- Conduct counseling to the community to form a sense of love for the history and culture of the nation and can increase community participation so that the Kota Tua area is increasingly recognized by the wider community 
- Carry out workshops / workshops on national and international perspectives for the development of the Old City of Sawahlunto in the tourist destination of the old town of Sawahlunto

- Research on cultural heritage buildings along the Old City Area.

- Giving appreciation to artists, history and humanists who have been instrumental in the preservation and development of old city tourism.

Strategy 3:

Facilitate the community in terms of the achievement of the Program

location and activities in this strategy are:

Busway procurement program to support tourism activities.

Activities:

- Increase the number of officers, to improve security and comfort during the trip so that more people will come to visit the old city, especially the Old Town area.

- Provides tourist transportation modes in the form of shuttle buses

- Use the busway feeder-feeder that goes to the study location

Strategy 4:

Utilizing tourism support facilities to support tourism activities

Target:

Creating a comfortable environment for local people and visitors. Programs and activities in this strategy are: Program to increase tourism support facilities in Kota tua Sawahlunto, namely by conducting activities:

- Arranging the parking lot

- Increase the number of restaurants

- Providing facilities for people with disabilities

- Make a plaza / interaction room at the study location

\section{Long term strategy}

Strategy 1

Improve promotion by utilizing the potential that exists in the Target study area: Realizing the image of Sawahlunto Old City Region as an old city tourism destination

- Programs and activities in this strategy are: Promotion programs, which can be carried out with the following activities: - Create and disseminate information on tourist objects and attractions through mass media (print and TV media), pamphlets, and brochures which contains information in strategic places

- Conduct dialogues and interviews with community leaders, relevant government officials through mass media, both written and visual

- Organizing an election for an old city tourism ambassador 
- Organizing festivals, product exhibitions and regional cultures such as: regional art festivals, regional special food creations, creations of regional products, etc. .;

\section{E. Conclusion}

Based on the results of the above analysis in this study, several study findings were found, including:

1. Analysis of the tourism potential of Sawahlunto's old city towards the 4A tourism component (Attraction, Accessibility, Facilities and Ancillary) shows that this area has the potential of historical tourist attraction. The historical heritage of World War II in Sawahlunto is the main tourism potential that is stored. With historical tourism potential, foreign tourists are the target of tourists who are expected to visit Sawahlunto. In order for a historical tourism potential strategy to be implemented, it is necessary to meet the minimum criteria of the tourism component. To meet the service standards of all $4 \mathrm{~A}$ tourism components, it is necessary to improve the management of 4A tourism components including Attraction, Accessibility, Ancillary, Amenity.

2. The development strategy of the Old City area of Sawahlunto uses a lot of SWOT analysis, namely by increasing and optimizing natural resources through good processing, improving road access, and improving tourism sectors in the Old City of Sawahlunto or fish. Improving human resources through counseling and training, socialization of science and technology.

3. The community involved in the management of the Old City Jakarta Tourism Object in Kota Tua Sawahlunto, the surrounding community and visitors. The function of the community in the management of tourism objects in Sawahlunto Old Town, among others, is the function of the community is to enliven or enliven the atmosphere in the Old City of Sawahlunto and as an icon or characteristic for the Old City of Sawahlunto. Existing communities also provide aspirations in the form of criticism and suggestions in terms of policy making or planning formulation. The function of the surrounding community is to maintain the security, cleanliness and sustainability of the Old City of Sawahlunto. In addition, the form of concern for the surrounding community is also needed in maintaining sustainability and maintaining historical value in the Old City of Sawahlunto.

\section{F. Recommendation}

1. In developing the tourism sector in the future, the City of Sawahlunto should focus on developing the superiority and characteristics of the city of Sawahlunto from the legacy of its mining history. The construction of a new tourist object that is short in nature such as Waterboom, Kandi Animal Park, and so on, is indeed able to attract visitors to the tourist attraction, but has not been able to provide a strong character towards the development of mining tourism in accordance with the City's vision. 
2. To develop a cultured mining tour, the Sawahlunto City Government should pay more attention to cultural excellence which is a cultural mix of various ethnicities. In addition, the Sawahlunto City Government must also clarify the ownership status of potential land and buildings, so that the characteristics of the mining tourism city get stronger. In addition, in preparing a more professional mining tour, the Government needs to improve the quality and capacity of the apparatus, especially in archeology and curators.

3. Development of promotion of Sawahlunto Old City area, West Sumatra by following national events such as Sawahlunto Calendar of Events, Kota Tua Festival 2, and Sawahlunto Multiculture in Harmony, in collaboration with travel agents to sell tour packages, media development media promotion print such as brochures, tourist books, tourist maps and online media such as blogs, websites, facebook, twitter, youtube, and other social media. Promotions can also be made by placing banners or banners on the attractions of Sawahlunto Old Town as a tourist destination in a location that is a tourist stopover such as airports, stations, and other strategic locations.

4. Accessibility development that makes it easy for tourists to go to tourist sites including roads, transportation, directions and others. Accessibility development can be done by transferring functions as a transit center for tourist vehicles, then from the transit location of tourist vehicles provided special transportation that connects between sites in one area of the Old Town of Sawahlunto which are traditional in nature such as buggies, rickshaws, rabbit trains, ontel bikes, etc.

5. Development of tourism facilities or facilities that support tourism activities such as the use of majapahit houses as homestays. The use of the Museum in Sawahlunto as a Tourism Information Center which also simultaneously sells tour packages. Then the concentration of the location of handicrafts can also make it easier for tourists to look for souvenirs or souvenirs from Sawahlunto.

6. Addition of supporting facilities such as health clinics that are open 24 hours and located near tourism sites, tourism security posts that are tasked with supervising and controlling tourism activities in each site, procurement of money changers, addition of ATM facilities near tourist sites and others other.

7. Establishment of the Management Body of Sawahlunto Old City area which consists of aspects of government, private and community. This management body was formed to clarify the authority and responsibility so that the development and management of the Old Town of Sawahlunto was more directed and not overlapping.

8. Development of human resources in the field of tourism both managers and the public in general. HR development is carried out by conducting routine socialization or counseling on cultural preservation and tourism awareness, 
Strategy For Development Of Old City As Tourism Destination In Sawahlunto City,

West Sumatera

conducting trainings related to tourism development such as hospitality training, leadership training, information technology training, homestay management training, entrepreneurship training and so on.

\section{REFERENCES}

Ardhika Sukmasakti Hasworo (2012) "Strategi Pengembangan Obyek Wisata Batik Kota Pekalongan”. Skripsi Tidak Diterbitkan. Fakultas Ekonomika Dan Bisnis Universitas Diponegoro Semarang.

Arikunto, Suharsimi. (2006). Manajemen Penelitian. Jakarta: Rineka Cipta.

Arikunto, Suharsimi. (2012). Prosedur Penelitian Suatu Pendekatan Praktek. Jakarta: Rineka Cipta.

Ashartono, Rakhmat., Myrza Rahmanita., and Diena Mutiara Lemy. 2018. The Effect of Destination Management and Community Participation to The Visitors Consumption at Tebing Breksi Sleman Yogyakarta. Tourism Research Journal. Vol. 2, No. 1: 1 - 13.

Bungin, Burhan. 2011. Penelitian Kualitatif. Jakarta: Kencana Predana Media Group

Damanik, Phil Janianton. 2013. Pariwisata Indonesia: Antara Peluang dan Tantangan. Yogyakarta : Pustaka Pelajar.

Freddy Rangkuti. (2005). Analisis Swot Teknik Membedah Kasus Bisnis. Jakarta: Gramedia Pustaka Utama.

Ronchetti, Jan L. 2011. An Integrated Balanced Scorecard Strategic Planning Model for Nonprofit Organizations. Journal of Practical Consulting. Vol. 1 Iss. 1, 2011, pp. 25- 35

Spillane, James J. (1987). Ekonomi Pariwisata, Sejarah dan Prospeknya. Kanisius.

Sugiama, A Gima. (2011). Ecotourism: Pengembangan Pariwisata Berbasis Konservasi Alam. Bandung: Guardaya Intimarta.

Sugiyono. 2014. Metode Penelitian Pendidikan Pendekatan Kuantitatif, Kualitatif, dan R\&D. Bandung: Alfabeta.

Sunaryo, Bambang. 2013. Kebijakan Pembangunan Destinasi Parivisata Konsep dan Aplikasinya di Indonesia. Yogyakarta : Gava Media.

Suprina, R., \& Nathania, A. (2018). How To Develop Kampung Wisata Batik Pesindon As A Tourist Destination In Pekalongan Through SWOT Analysis. TRJ Tourism Research Journal, 2(1), 14-27. doi:10.30647/trj.v2i1.25

Suwena, Widyatmaja, 2010. Pengetahuan Dasar Ilmu Pariwisata. Denpasar : Udayana University Press

Yoeti. 2008. Ekonomi Pariwisata. Jakarta: PT.Kompas Media Nusantara.

Other Sources:

RTRW Kota Sawahlunto 2017-2030

http://sawahluntotourism.com/index.php/About-Us-Tentang- Sawahlunto/ kunjunganwisatawan-Kota-Sawahlunto 